International Journal of Islamic Economics and Finance (IJIEF)

Vol. 3(2), page 119-144, Special Issue: Islamic Social Finance and Ethics

\title{
Contemporary Issues on Cash Waqf: A Review of the Literature
}

\author{
Khaled Nour Aldeen \\ Airlangga University, Indonesia, Damascus University, Syria \\ Corresponding email: khaled.knd@hotmail.com \\ Inayah Swasti Ratih \\ Airlangga University, Indonesia, inayah.swasti.ratih-2018@pasca.unair.ac.id \\ Sri Herianingrum \\ Airlangga University, Indonesia, sri.herianingrum@feb.unair.ac.id
}

Article History

Received: May $30^{\text {th }}, 2020$ Revised: July $17^{\text {th }}, 2020$ Accepted: August $28^{\text {th }}, 2020$

\begin{abstract}
This paper presents the most recent works on cash Waqf, focusing on identifying contemporary scholars' work in this area, providing a novel framework to indicate the existing gap, subsequently, it opens the door wider for new research commitment. This research adopts the paradigm of qualitative approach research, based on disk-based research. Google Scholar was employed, searching through the passage. Only contemporary English documents within the period of 2002-2019 were the subject of this study. Lately, cash Waqf has been proven as a proper method for poverty alleviation. Previous studies attempted to address several models in order to enhance socio-economics issues. This research is a distinct attempt, as to the best of our knowledge, there is no previous research addressed the subject matter. Moreover, this study is expected to assist the interested scholars by offering comprehensive conclusion about have been done in the field. Hence, opens new doors for scholars to develop new innovative cash Waqf models to bridge the socio-economic issues. Our findings depict that Malaysian and Indonesian scholars show a robust research commitment on cash Waqf during 2002-2019. Furthermore, this study highlights the existing gap that must be researched to enrich the potentials of cash Waqf, future research should address other countries practices in term of cash Waqf, moreover, validating a proposed model through interviews to ensure that a proposed model is applicable. In terms of cash Waqf awareness, research might consider peer influence", "self-efficacy in contributing to cash Waqf.
\end{abstract}

Keywords: Waqf, Cash Waqf, socio-economic, social welfare, sustainable philanthropy. JEL Classification : 131, 130, P36

@ IJIEF 2020 published by Universitas Muhammadiyah Yogyakarta, Indonesia All rights reserved

DOI:

https://doi.org/10.18196/ijief.3236
Web:

https://journal.umy.ac.id/index.php/ijief/article/view/8923

Citation:

Aldeen, K. N., Ratih, I. S., \& . Herianingrum, S. (2020). Contemporary issues on cash waqf: A review of the literature. International Journal of Islamic Economics and Finance (IJIEF), 3(2), 119-144. DOI: https://doi.org/10.18196/ijief.3236 


\section{Introduction}

\subsection{Background}

Islamic finance is growing rapidly in the contemporary world particularly during the last few decades. Many countries are contesting in socioeconomics sector to enhance society's well-being. For instance, Indonesia, Malaysia, and Saudi Arabia as Muslim majority countries. In addition to Singapore and Nigeria as Muslim minority. Principally, Islamic economy not limited to the material profit could be attained from the current life rather than considering both the current world "Dunia" plus the hereafter "Akhira" which is considered Muslims' ultimate goal (Kahf, 1999). Whereas, conventional economy is materialistic and profit-oriented in its nature. This the core difference between Islamic banking and economy compared to its counterparts. The conventional economy is man-made, it's also the subject of being used against him or rather being expired for a certain time. The main reason that the Islamic economy and finance have received this high consideration during the last few decades is attributed to their, potential, certainty and quality in uplifting economic development and growth of the human being, aptitude in terms of poverty reduction and socioeconomics welfare. Moreover, promoting livelihood standards through special instruments so-called Waqf, Zatakat, Sadaqah, and Infaq among of society members.

Mubyarto (1988) stated that welfare indicators are as follows, clothing, sufficient food, health maintenance, shelter, feeling of being treated fairly in life, and educational achievement of children all effectively addressed by Waqf institutions. Furthermore, Waqf has performed well in the field of the assurance of the five essentials (Al-Daruriyaat al-Khams): protection of life on the essentials; protection of the religion and religious activities; protection of the body; human intellect with sound and harmonious mind's development, and soul through educational services; protection of widows and orphans; and protection of income; wealth and reallocation of wealth through economic activities (Alam et al., 2018; Kahf, 1999; Abdullah, 2018). The most common and discussed aspect of the Islamic economy and banking is the prohibition of usury (Riba). The Islamic scripture (Qur'an) stresses on the prohibition of usury in several verses (Qur'an, 3:130-131).

Islamic economics work differently from the traditional framework. The Islamic one, however, refers to a system that operates according to Islamic law (Shariah), which predominantly prevents charging extra money for the borrowed money, it is based on (PLS) profit-loss sharing where all the financial transactions are assets-backed. Furthermore, it does not permit 
investments in any prohibited products, for example, pork (Qur'an, 1:173) and alcohol as the in (Qur'an, 1:219).

The main dimensions of Islamic economics are to enhance the social welfare, social security, debt, management and distribution of wealth, consumption, taxation, debts, monetary policies, market exchange and investment (Shinkafi and Ali, 2017). The subject matter has received and contemporary researches' attention worldwide. Especially in the last decades. Waqf is considered as an effective socio-economic tool represent part of Islamic ethical values of Islam and counted among financing vehicle that serves Islam and society.

The implementation of cash Waqf has attracted many researchers' attention to consider the potential and influences of this method of finance. However, to the best of authors' knowledge there is no previous study addressed thoroughly what have been done in this area. Among the reason of the recent comeback of cash Wagf in the temporary context is due to its flexibility, it allows all Muslims segments to participate in Waqf activity regardless to the amount of money. Moreover, more practical to distribute its benefits among the wider segments of receivers, uncomplicated to manage and easy to utilize for the beneficiary's daily necessities.

Waqf issues have taken this significant place due to the efforts have been done by contemporary scholars, revealing the benefits associated with Waqf practices including its applications in contemporary society plus addressing associated challenges. Most of the reviewed research stressed that cash Waqf is an efficient instrument can be an alternative for poverty alleviation, since such an initiative require a tremendous amount of money that could not be attained totally by the government. Hence, seeking for a sustainable source if fund is inevitable. An indispensable part of Islamic socioeconomics, cash Waqf is a social fund politically and economically free of charge. Moreover, it more powerful, permanent and pervasive since it is cardinally voluntary activity characterized by perpetuity. Upon to the aforesaid, this research is an attempt to address what has been done in this area, subsequently will open new doors for scholar to address the potentials and challenges related to the field. For instance, find innovative ways to manage cash waqf systems and create a hybrid-sustainable cash Waqf model to generate more benefits for all involving parties. Therefore, it is crucial to seek for the enhancement of Waqf institutions role in the current socioeconomic conditions. 


\subsection{Objectives}

Mainly, our literature review aims to address three main areas. First, presenting what has been done by scholars in the field. Secondly, highlighting the main topics that attracted the contemporary scholars' attention. And lastly, identifying the existing gap for future research.

The reminder of the paper is arranged in following chronological order: first start with Waqf definition and its legitimacy, followed by research methodology, next discussion and ending up with the conclusion.

\section{Literature Review \\ 2.1 Background and Theory}

\subsubsection{The term Waqf}

Before discussing the main research question, let us tackle what is the essential characteristic of Waqf, and its permissibility from Islamic perspective.

In the Arabic language, singular Waqf and the plural Awakaf means to stop, preserve, or contain (Shukor, Anwar, Aziz, \& Sabri, 2017a). In the Islamic context, Waqf Simply interpreted as holding an asset (Maal) and limiting its consumption to frequently extract its usufruct for the benefit of an objective representing philanthropy/righteousness (Qudamah 1998; Kahf, 1999; Mahamood, 2006). Waqf is endowing a property for philanthropic goals seeking reward from Allah (SWT) (Kahf, 2003). Hence, the control of Waqf property lies outside the individual who endowed the Waqf property. Waqf is permanent, neither refundable nor returnable, and disposition of it outside the particular objective is prohibited (Yusof, Hasarudin, \& Romli, 2014). In other words, Waqf is a gift that will keep giving until the Day of Judgment. Two models of prominent Waqf are the immovable property ('Aqar) and movable (Manqul) property (Mahamood, 2006). Waqf is an endowment made by the wealthy to serve the needy. Basically, four parties contribute with Waqf property as follows (Khademolhoseini, 2008):

- Waqif (endower);

- Nadzir (Waqf manager); (in the case of cash Waqf, Nadzir he is obliged to maintain the fund in a way that keep the original amount)

- Mawquf 'alaih (Beneficiaries); and

- Mawquf (property or Cash as property). 
It is one of the essential components in Islam in mitigating poverty through granting primary needs to improve the universal welfare of people and or has the strong economic dynamism to pave the path of growth to facilitate the society's growth (Aliyu, 2019; Kahf, 1999). Apart from the relationship between mankind and Allah (SWT), Waqf also relates to people's affairs among each other's (Aliyu, 2019). According to Nadwi, (2015) Waqf institution serves two purposes. On the one hand, provide a perpetual reward for the donor. On the other, it is in the interest of the whole community in general. Alam, Shahriar, Said \& Monzur-E-Elahi (2018) stressed that through Waqf institutions the living standards of Ummah can be uplifted. Moreover, reduce the poverty and difficulties among the needy and poor.

Through Islamic history, Waqf has witnessed tremendous development, since its early stages in the prophet Muhammed era until the present moment. To be mentioned, the very first Waqf in Islam was Quba mosque in Al Madinah, it was established upon the profit Muhammed (SAW) arrival in 622 A.D (Laldin, 2005). Throughout the reign of the Khulafa' al-Rashidin and the subsequent period of Islamic ruling Waqfactivities were further extended. This kind of Waqf referred to a type of Waqf, which essentially concern the religious, philanthropic, posterity of family and educational purposes.

Since the very beginning, numerous educational institutions have been financed employing Waqf funds, for instance, there were 60 Awqaf schools established by Awqaf properties in Palestine. Moreover, Syria and Turkiye (of which 40 had been established by Ayubite governors (Kahf, 2003). The University of al-Azhar in Cairo alone is financed by numbers of Awqaf (established in October 975 AD) (Aliyu, 2019).

\subsubsection{The Term of Cash Waqf}

Typically, Waqf practices ordinarily centered on the building or land. However, many donors cannot afford an asset to participate in Waqf. Hence, cash Waqf has come as a good option for donors who do not have a fixed asset but rather have movable assets i.e. cash for donating. Thus, all the strata of the society are able to perform sustainable charity activities through cash Waqf as long as they keen on doing it voluntarily only for the sake of Allah SWT blessing (Mohsin, 2008). Cash Waqf practices could be categorized into two ones, the first so-called is the direct one, for instance, channel waqf money to redevelop an old waqf property. The indirect form of cash Waqf where the fund invested in a particular permissible project and distributing its profit (Mohsin, 2013). 
A sizable number of present scholars accept that participation in Waqf in the form of cash becomes crucial (Mohsin, 2008). However, over the years, the role of Waqf in the socio-economic area has decreased significantly (Saifuddin, Kadibi, Polat, Fidan, \& Kayadibi 2014). The practice of cash Waqf is not a new phenomenon. The first cash Waqf in Islam has been approved by Imam Zufar in the eighth century (Sanusi and Shafiai, 2015). It was effectively employed during the Ottoman era. Pitchay, Meera, \& Saleem (2015) showed that by the end of the 16th century, the term of cash Waqf was fully accepted by the whole Antonia and the European territories of the Ottoman Empire which correspondingly managed some parts of the Middle East, South-Eastern Europe and North Africa. During that time, the collections in the cash Waqf were used to acquire and improve several models of fixed assets.

Saifuddin et al. (2014) highlighted four notable implementations of Cash Waqf: i) It is accessible since it only requires a small amount of cash, which enables those who cannot afford to endow an asset; ii) Creating a backup fund for educational institutions that face a cash flow problem; iii) Generate funds for the improvement of Waqf assets (Waqf lands); and iv) Boosting Islamic institutions to be more independent, and release the pressure from the government back. Furthermore, cash Waqf can be employed for financing purposes, such as the development of Waqf properties through acting as medium such as musharkah and mudarabah contracts.

\subsubsection{Legitimacy of Waqf}

Flashback to the legitimate (Waqf), we find that the scholars have been rooted Waqf with many evidences of the Qur'an and the Sunnah (the teachings and practices of Muhammad) and the consensus. Although they do not indicate the subject of the endowment directly, it urges the acts of righteousness and goodness. There is no single verse in Qur'an refer to endowment (Waqf) in a strict way, but Waqf activities can be associated to many verses indicate the philanthropy and charity (Qur'an,1:280; Qur'an, 3:116; Qur'an, 5:35 Qur'an; 2:276; Qur'an 2:261 Qur'an, 2:110 Qur'an, 73 :20 Qur'an, 2:43 Qur'an, 3:92 Qur'an, 2:273).

What is more, Islam has several (Ahadeeth) narrated from Prophet Muhammad (SAWS) indicates the importance of Waqf, and his Waqf contribution for instance:

"A single sadaqa closes seventy gates of evil (al-Ghazali, $\mathrm{n}-\mathrm{d}$ ). 
Additional to (Sunnah), prophet Muhammed companions have recorded a notable Waqf contribution. For instance, Uthman bin Affan R.A. It was narrated that the Prophet (SAW) called upon Muslims to buy the well and provide the water free for the public upon realizing that water was traded at a high price. Uthman bin Affan R.A responded to the Prophet Muhammed (SAW) call by acquiring the well and rendering the water for the public free (Saifuddin et al., 2014). The granting of benefit to the detainees is based on its contribution to preserving the donator dignity to draw closer to God Almighty. This giving is expressed by the charity that the Prophet (SAWS) has urged. The charity based on endowment Waqf is sustainable, on the other hand, the charity, which intended to expire, its works as paracetamol. Same as all Islamic activities, Waqf activities must not contravene the roles of almighty Allah. The Shari'ah scholars: Imam Hanafi, Imam Hanbali, Imam Maliki's and Imam Shafi'i and concur on perpetual Waqf. However, from Imam Maliki's point of view, it is permissible to be temporary (Aliyu, 2019). The Malikis, for instance, establishes that the Waqif has the right to determine a particular period for the contract, which by its end, the property returns to him after a defined period of time. To be mentioned, Waqf practices is only deemed to be only for Muslims, while it could be donated by non-Muslins as well (Puad, Rafdi, \& Shahar 2014).

\subsubsection{Legitimacy of cash Waqf}

Hanafi, Maliki, Shafi'i, Hanbali schools have confirmed the legitimacy of moveable Waqf (Mohsin, 2013). However, jurists differ on the permissibility of cash Waqf even though it is counted under moveable Waqf. The Hanafis and Shafi'is fix that cash Waqf is impermissible, the Hanbalis and Malikis say it is permissible (Aliyu, 2019). Al-mujamma' al-fiqhi (Islamic Fiqh Academy) in its fifteenth meeting, issued a statement No. 140 that countersigns that cash Waqf is permissible. Likewise, on May 11 2002, "Ulama Council" in Indonesia issued a fatwa declaring that cash Waqf is allowed (endowment cash/waqf al-nuqud) on condition that the principal value of endowments must be guaranteed sustainability (Aliyu, 2019). They attributed their fatwa to general dalil in the Qur'an which related to the managing cash Waqf in indirect way, Surah al-Baqarah 215, 254 and 267, Surah al-Imran 92, in addition to hadith narrated by Ibn Umar (Muslim, Hadith No. 1632), as well as to the ijtihad (independent reasoning). In 2007, the Malaysian National Fatwa Council concluded that cash Waqf is permitted in Islam (Rahman, 2009).

All Muslims jurists fix that once a property is confirmed as Waqf, it will be under three restrictions (AI-Zuhaili, 2004). The same should be implemented in the case of Cash Waqf (Mohsin, 2013), namely: i) Irrevocability: when a 
founder endows a cash Waqf, he cannot revoke it, in some special cases ca take enjoy part of the profit; ii) perpetuity; and iii) inalienability: it cannot be the subject to any, inheritance, gift, or any alienation whatsoever.

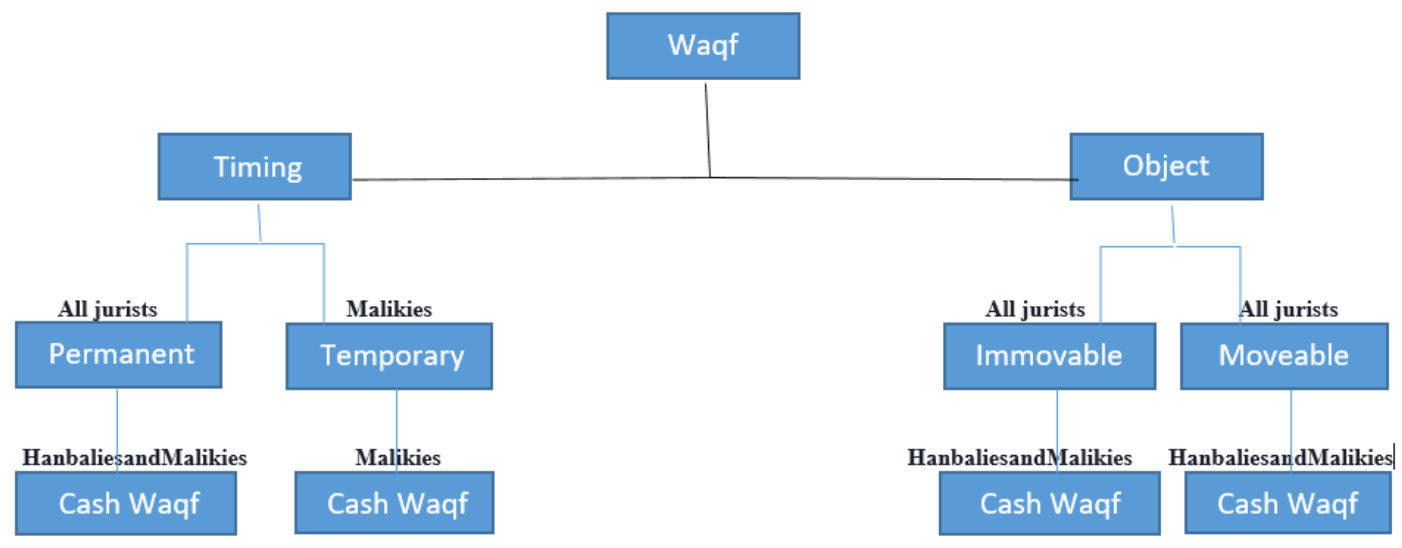

Figure.1 The categories of Wagf according to (Hanfi, Maliki, Shaf'I, Hanbali)

\subsection{Previous Studies}

In this section we attempt to present the outlines of the studied literature plus related reviews has been done in this area. A detailed explanation will be presented in the next section since this article is a literature review one.

The early presence of cash waqf studies mainly addressed the poverty eradication through this sustainable instrument. Masyita, Tasrif, \& Telaga (2005) study was among the early studies that suggested cash waqf tool to eradicate poverty. However, there are a wide range of research addressing cash Waqf. Previous studies mainly attempted to associate Cash Waqf with microfinance (Zabri and Mohammed, 2018), small- and medium-sized enterprises (Amuda, Embi, \& Babatunde 2014), education (Aziz, Johari, \& Yusof, 2013), factors influence the contributors (Witjaksono, 2018), management (Siswantoro, Rosdiana, and Fathurahman, 2018), E-cash Waqf (Yusof et al., 2014), and socio-economics development (Sanusi and Shafiai, 2015). Atan and Johari (2017) aim to examine the 2006-2016 literature of Waqf dealing with the topic poverty alleviation; the writers concentrate on the publications' years, the number of the contributors, and the country of a study. They use the open access Mendeley database to retrieve relevant information. As hundreds of studies they confirmed that Waqf is an efficient method to alleviate poverty. On the other hand, the contemporary scholars are focusing on maximizing the benefits of cash waqf, for example Nadya, Alwyni, Hadiyati, \& Iqbal (2019); while others concentrate on the Waqf manager accountability (Siswantoro et al., 2018). 
Our study differs in many aspects; the firs, is the in-hand study concentrate on the cash Waqf; we attempt to narrow the research topic to end up with reliable conclusion. Secondly, this study not only counting the article rather than it summarizes the conclusion of the research counted in the results. This research is a distinct attempt in nature since there is no previous study presented what has been done in this area. This research will highlight the main areas has been associated to Cash waqf practices and highlighting what has been missed in the literature.

\section{Methodology}

\subsection{Data}

This study relied on the finding based on the selected keywords mainly "Cash Waqf" and "Waqf" "Islamic socio-economics" "Zakat, Infaq, Sadaqah". Prior to the review phase all the recovered documents relevancy was evaluated based on the title, abstract, conclusion, and addition to bibliography. Some papers seem not relevant to the main topic "Cash Waqf" but these papers were used in the next phase, which is reviewing the reference list thoroughly seeking for further articles related to the subject of "Cash Waqf". All the selected article has to include information suggests its relevance to the topic of "Cash Waqf". To be mentioned, documents that do not indicate the subject of "Cash Waqf" has been excluded. The main purpose beyond narrowing the research question to cash Waqf, is to end up with, exhaustive summary of current evidence relevant to "Cash Waqf". Generally, all article dose not research cash Waqf in direct or indirect way plus article are not written in English were excluded from the in-hand study. Wholly, published studies were downloaded employing Google Scholar. However, only articles were considered relevance significantly to be scored as part of this result. The idea of Cash Wagf is thus relatively brand-new as compared to its common applications (Siswantoro and Dewi, 2007). Research that shed lights on cash Waqf implementation and opportunities has been commenced in the last decade, resulted from newly allowing cash Waqf practices in countries, for instance, Indonesia "Ulama Council" in 2002 (Aliyu, 2019). Followed by another fatwa from the "Malaysian National Fatwa Council" in 2007 (Rahman, 2009). Therefore, the span of this study was (2002-2019). In all, 74 references were used in this research, while only 57 references were found significantly related to the subject of cash Waqf to be scored the part of the result. 


\subsection{Method}

The literature review is used in this study, collecting secondary data, this is followed by synthesizing the data qualitatively and quantitively. Hence, provide a comprehensive summary of current literature related to the "Cash Waqf". The exploration processes started in October and ended in November 2019. The research phases employed in this study were used by Shinkafi and Ali, (2017) as follows:

- Documents that match with the search keywords;

- Seeking for more relevant references in the bibliography of the downloaded articles to expand the retrieved data.

Rstudio software were employed to analyze the data and extract the visuals. This software commonly used for visual programming particularly in the case of literature review studies (Aria, and Cuccurullo, 2017).

\section{Results and Analysis}

\subsection{Results}

To present the result of this study, the full title of the 57 scored paper presented in figure. 4 to identify its relevance to the subject matter. To ease the analyses, eight themes connected to cash Waqf were identified. To be said, some papers correlated to more than one them, but to avoid duplication the dominant content of the paper was mainly considered to categories each article. After deciding these eight themes, a second searching round employing Google Scholar to ensure that no related articles are lifted behind.

Figure 2 shows the number of the accessed documents each year spanning 2002-2019, the result during the stated period present a significant advancement after the declaring the permissibility of cash Waqf in Indonesia and Malaysia, and started increase significantly starting from 2006, that could be attributed those two announcements have spotted the light of the cash Waqf. The period 2012-2018 witnessed extraordinary growth, most of the contemporary scholars moved to the socio-finance due to its positive consequences. However, in 2019 the number slightly declined, probably many related articles have been accepted and not published yet.

Figure 3 illustrates the contribution of each theme during the study period. Title 5 and 7 have the highest percentage of 23\% and 21\% respectively, revealing that the contemporary scholars concerning the management of cash Waqf and the factor influence cash Waqf contributions rather than 
Aldeen, Ratih \& Herianingrum | Contemporary Issues on Cash Waqf: A Review of the Literature

other aspects. Title 1 and 8 recorded a significant result compared with titles 3,4 and 6 . Whereas, title 2 recorded the least effect with $3 \%$.

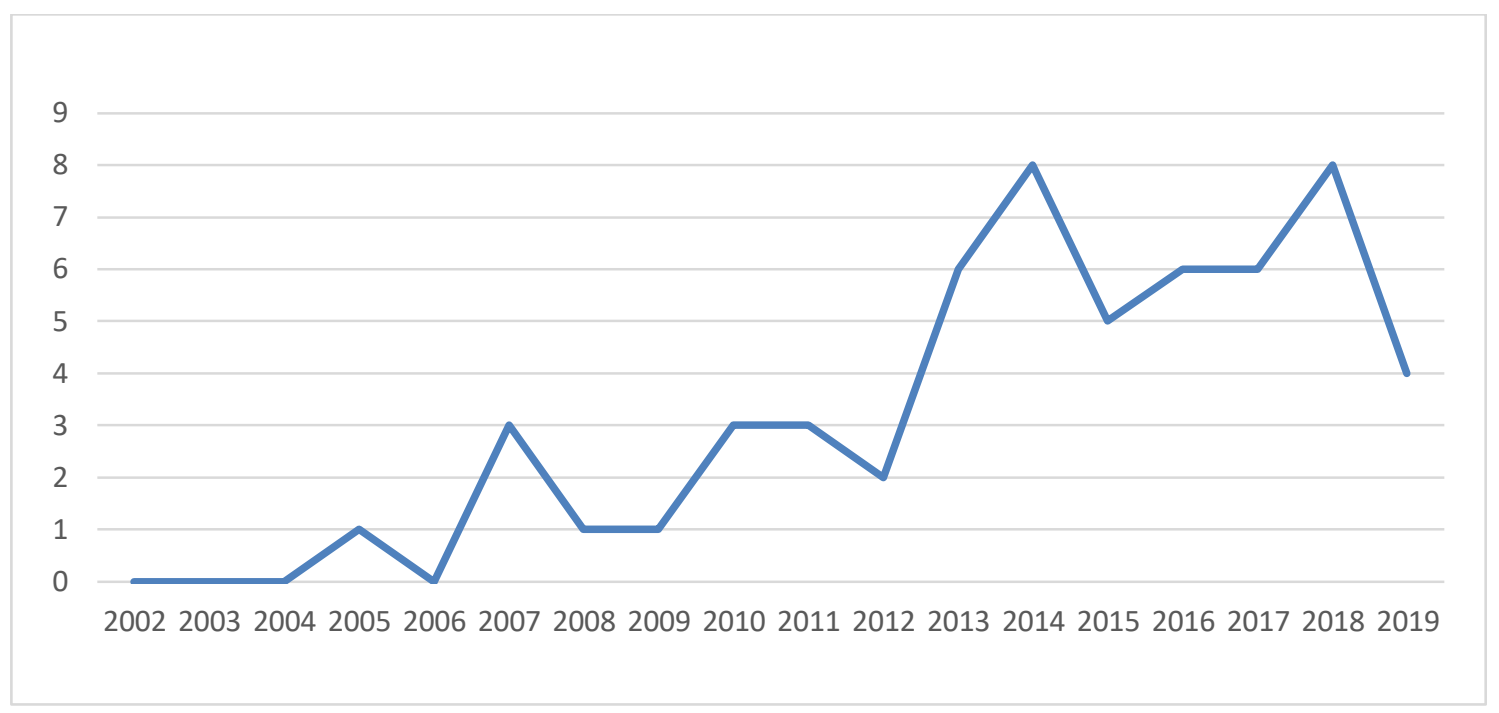

Figure 2. Number of the articles per year.

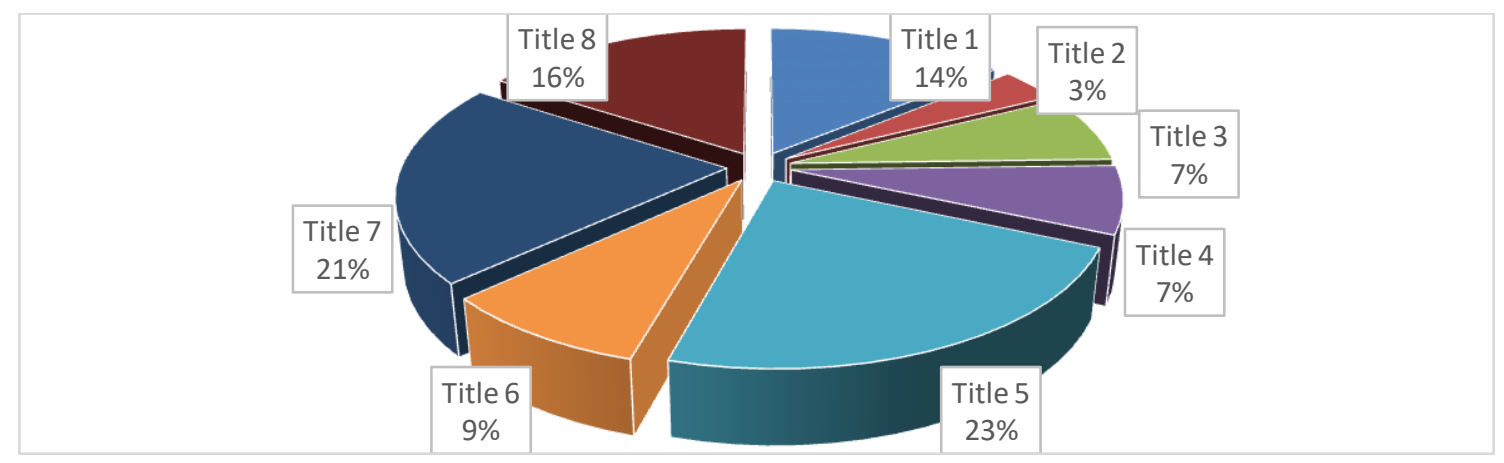

Figure 3. Documents' analysis per title.

The consequence of systematic literature review could be categorized into several themes as follows:

- Cash Waqf for microfinance (4 articles)

- Cash Waqf for small- and medium-sized enterprises (8 articles)

- Cash Waqf for education (2 articles)

- Cash Waqf for poverty alleviation (4 articles)

- Factors influence the contributors of Cash Waqf (13 articles)

- Management of the cash Waqf (12 articles)

- E-cash Waqf (5 articles)

- Cash Waqf for socio-economics development (9articles) 


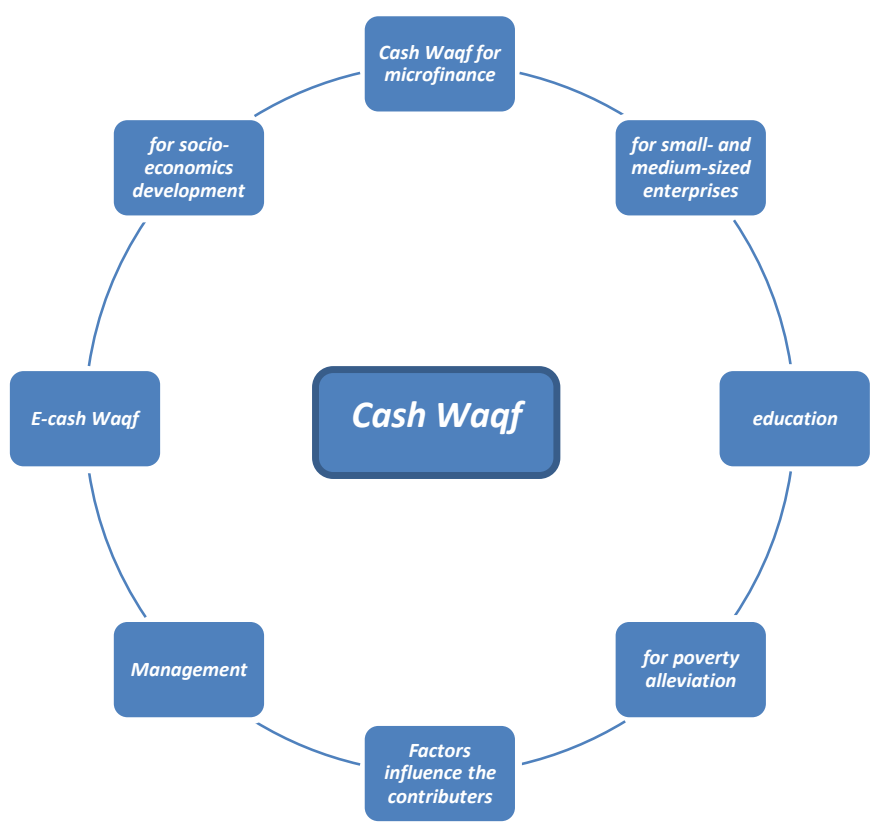

Figure 4. Structuring exogenous research topics

\section{Cash Waqf for microfinance}

Islamic microfinance institutions lacking the economic and financial sustainability of the financing modalities employed. Hence, produce often very little social impact (Nadwi and Kroessin, 2013). Cash waqf can enhance the accessibility of microfinance institutions to access financial markets. Zarka (2007) stresses that cash Waqf is an efficient method to alleviate poverty through bridging cash Waqf donations to relieve the poverty of those who cannot fully support themselves. Furthermore, he confirmed that cash Waqf is a proper way to combat poverty fulfills a major economic goal in Islam. Kachkar (2017) introduced cash Waqf microfinance fund (CWRMF) in order to bridge microfinance facilities to refugee entrepreneurs who are capable to run their businesses. This model employed cash Waqf donations to serve microfinance facilities. Zabri and Mohammed, (2018) examined the behavior intention to participate in \{Cash Waqf-Financial Cooperative-Musharakah Mutanaqisah (CWFCMM)\} home financing model with four different form of normative influence namely; subjective norm, attitude, perceived cost benefits, perceived behavioral control of the proposed model, their results showed that subjective norm was determined to be as a significant factor in measuring the intention of the homeowners in Malaysia to participate in the model. Nadwi and Kroessin (2013) reviewed the socio-economic 
Aldeen, Ratih \& Herianingrum | Contemporary Issues on Cash Waqf: A Review of the Literature

and figh (Islamic jurisprudence) issues about cash Waqf permissibility. Moreover, he stresses that hybridization of cash Waqf and microfinance can offer an innovative way to enhance access to development finance.

\section{Cash Waqf for small- and medium-sized enterprises}

Mohsin (2013) addresses a new model that CWFI cash Waqf financial institution can be employed by any Muslim societies to fulfill a social need and uplift their living standards, without depending on the governments. CWFI can assess entrepreneurs with Qard Hassan loan/free-interest loans in order to commence their businesses. Duasa and Thaker (2016) stressed that through cash Waqf a country's GDP can be accelerated by bridging the donations of cash Waqf to microenterprise financing. Furthermore, it has been found a high level of readiness of the micro-enterprises in accepting the model as a source of financial and human capital development. Another model as source for small enterprises has been approached by Duasa and Thaker (2015 \& 2016) and Thaker et al. (2016) the proposed a new financing model \{cash Waqf micro-enterprises investment (ICWME-I)\} for microenterprise through an agreement between cash Waqf institutions and micro enterprises through musharaka mutinaqisa to finance projects and businesses. Nevertheless, Thaker et al. (2016) confirm the feasibility of this model by interviewing experts from different backgrounds. Another study addressing this model by Thaker et al. (2016) to examines the intention of micro-enterprise to adopt such a model ICWME-I the findings indicate that both the subjective norms and attitude are seen to have a positive significant impact on the intention of micro-entrepreneurs to use the ICWME-I Model in Malaysian context. Another study by Lahsasna, (2010) addressed the role of cash Waqf to enhance and develop the financial services for micro and medium-sized enterprises (MMEs). An interesting study by Amuda et al. (2014) discussed the possibility of using cash Waqf funds between nations (Malaysia-Nigeria) relaying on the excelled Nigerian agriculture sector. 


\section{Cash Waqf for education}

As a result of the importance of education for the development of human capital and its impact on the economic growth (Wafa, 2010). Wafa (2010) promotes the third sector of Islamic economics through benevolent and educational programs. Aziz et al. (2013) design a new cash Waqf model for education financing through Waqf bank, waqf bank can be entrusted to with cash Waqf and collecting it from public and cannel it for education purposes. To ensure the perpetuity of the fund, a reserve account can be established to cover any default since the given loans are interest-free with minimum service charge.

\section{Cash Waqf for poverty alleviation}

Most of the reviewed studies indicated directly or indirectly that Waqf could be considered among the effective method to alleviate poverty, due to its sustainability. Saifuddin et al. (2014) attempted to examine the potential of cash Waqf to alleviate poverty in Malaysia due to the Malaysian government policies to alleviate poverty, their findings show that cash Waqf can be used as an effective tool to eradicate poverty because cash Waqf reached great lengths in these recent years. In the case of OIC countries Amuda and Embi (2013) analyze the forms and extent of funding that may be spent in established voluntary organizations such as Waqf properties, public funding, and sadaqah to create employment to decrease the poverty rate in OIC countries. Masyita et al. (2005) developed a cash Waqf model in order to assess SME's as an alternative to alleviate poverty in Indonesia.

\section{Factors influence the contributors of Cash Waqf}

Witjaksono (2018) attempted to examine the customers' intention to donate cash Waqf through Islamic banks in Indonesia, the author stressed that Behavior, Religious Commitment, Subjective, Attitudes, influence cash Waqf donation through Islamic banks. Affandi and Nufus (2010) find that cash Waqf contributions still far from its expectations.

Rizal and Amin (2017) investigated the role of Islamic religiosity, Islamic egalitarian and perceived ihsan on cash Waqf contribution in 
Malaysia, their findings indicate a significant relationship between the studied factors and cash Waqf contribution. Shukor et al. (2017a) in the case of Malaysia find that demographic can predict the donor/nondonor. Furthermore, they extended their study to confirm that trust and religiosity in Awqaf institution are predictors of Muslims' participation in cash Waqf (Shukor et al., 2017b). Osman, Mohammed, \& Amin (2012) tried to explain the role of demographic factor, religious satisfaction, trustworthiness, tax incentive, and efficient management to increase cash Waqf contributions. Another study that addresses the Malaysian context is done by Pitchay et al. (2015) who tried to explain the factors influents the employee to contribute in Waqf through salary deduction, verified the structural relationship between subjective norms, attitude and behavioral intentions of Muslim workers. In addition, the individuals' mindset will inspire Waqf endowers. It has been stated that the effect of attitude on behavioral intent is instrumental in understanding acceptance of cash Waqf (Shukor et al., 2015). Haron, Kamarudin, Fauzi, Ariff, \& Zainuddin (2016) recommended the increase of cash Waqf promotion in order to gain more collections since his findings illustrate the factors to influence this collection authority, promotion, method, place, and stuff. Concerning the theory of planned behavior, Osman et al. (2016); Ratnasari and Arifin (2017); Osman et al. (2014) confirm the validation of the theory to explain cash Waqf giving behavior. Adeyemi, Ismail, \& Hassan (2016) indicate that the level of awareness in Malaysia is in its low levels, awareness level was explained by the lack of promotion and lack of understanding. Johari, Alias, Aziz, Ridhwan, Kefeli, Ahmad, \& Ibrahim (2015) attempted to give insight about continuous cash Waqf contribution, they suggest that the popularity of contributing to cash Waqf continuity is more prevalent among married males of 36 to 40 years old and reside in the rural area.

\section{Management of the cash Waqf}

After the announcement of both Malaysian and Indonesian government, many Waqf institutions have been established (Nahar and Yaacob, 2011). Nadya et al. (2019) indicated that cash Waqf in Indonesia facing three main difficulties to reach its optimal level, regulations, Nazhir, and socialization. Another study addressed the Indonesian context by Nahar and Yaacob (2011) established that the 
Indonesian Awqaf institutions have a unique characteristic. Hence, they attempted to reconstruct the accountability of Waqf institutions in Indonesia. On the other hand, Chowdhury, et al., (2011); Nahar and Yaacob, (2011). In the case of Malaysia, attempted to examine the accountability, they stress that the accountability system in the country needs to be enhanced and uplifted. Further study in Malaysia examining the operation of cash Waqf and Its limitations, Mokhtar, Sidin, \& Abd Razak (2015) concluded that the lack of qualified Nadzir plus the multi decision-making process should be addressed to maximize the performance of a cash Waqf institution. In the same context Yaacob (2013) investigates some cash Waqf cases when civil law violates the Shariah law. Khademolhoseini, (2008) attempted to approach new models (mutual fund and cooperative) to maximize cash Waqf management. Since cash, Waqf practices were significant in the Ottoman Empire (Ibrahim, Amir, \& Masron, 2013; Toraman et al., 2007). Toraman et al. (2007) attempted to present cash Waqf accounting practices in the Ottman Empire era. A sole study concerned the case of Singapore by Karim (2007) discussing the administration and the management in the country, indicating that the country lacks expertise in the Waqf. It seems the same in the Indonesian context when Rusydiana and Devi (2018) state that Indonesian cash waqf institutions lack qualified human resources, efficient system, trust and fulfilled Waqf covenants. Mauluddin and Rahman (2018) discuss the permissibility of cash Waqf in Aceh (wellknown as Islamic district in Indonesia), they noted that the Aceh's scholars do not declare the permissibility of cash Waqf if it is not going to be linked with a fixed asset. Sulaiman et al. (2019) proposed unit trust model to enhance the performance of cash Waqf plus enlarge the base of cash Waqf collection.

\section{E-cash Waqf}

Lately, e-waqf increases the collection of Waqf electronically; motivate existing Internet banking users to contribute to Waqf activities. Moreover, enabling the collectors to make more funds to be invested to serve the development of the ummah (Yusof et al., 2014). Amin et al. (2014) attempted to investigate the factors influence the contribution of cash Waqf, perceived ease of use, religiosity, and usefulness plus the amount of information play a vital role in the 
contribution of cash Waqf. (Yusof et al., 2014) attempted to identify the challenges and the limitation of the conventional way of cash Waqf collection, he proposed that e-cash Waqf in Malaysia has great potential since the country enjoys advanced information technology. Only age among the demographic factors influence e-cash Waqf contribution in Malaysia (Perlis et al., 2014). A sole study in the Indonesian context by Victoria and Ong, (2019) stressing on the potential of the E-Waqf in Indonesia if and only if managed properly.

\section{Cash Waqf for socio-economics development}

Several studies pointed the potential of cash Waqf for socio-economic development, but in this section, we will discuss only articles which discussed thoroughly cash Waqf potentials for socio-economics development. Nurrachmi, (2012) and Suhaimi et al. (2014) discuss that through cash attained by committees of a mosque can be bridged to provide financing facilities. Alam et al. (2018) based on literature review, indicated that all types of Waqf including cash Waqf can be an effective tool for social welfare if utilized properly through synthesizing models to address current contexts. While Nurrachmi (2012) stresses the importance of availability of qualified nadzir to meet cash Waqf objectives. Ibrahim et al. (2013) indicate the potentials of cash Waqf to uplift ummah living standards using evidence from Ottoman Empire cash Waqf implications. Sanusi and Shafiai (2015) provide an evidence in Malaysia based on literature and interviews that cash Waqf is the alternative method toward societal development. Che Hassan and Rahman (2018) confirms that through cash Waqf can improve the development factors of Malaysian economy such as well-being, education, health, agriculture and religious affairs. Mohammad (2011) discussed the permissibility of establishment of Waqf bank based on cash endowments to serve the ummah national and internationally. Aliyu (2019) and Mohammad (2009) discussed all types of Waqf and its potentials enhance socioeconomics, but he insisted that cash Waqf should be priorities due to its flexibility and ease of collection. 


\subsection{Analysis}

This is unfortunate that most of the published papers address the Indonesian and Malaysia context. However, that cash Waqf had played a notable role in the development of socio-economic of Muslims in history (Aliyu, 2019). The principle of Waqf is to serve the well-being of society to the large extent (Alam et al., 2018). Furthermore, provide needs in a sustainable way to serve a community. It attends by covering the social work, health, education and economic activities such as business expansion, and other areas of societal work without depending on the government's budget (Mohsin, 2013). Hence, it goes beyond the religious activities. At the present time, issues have urged contemporary scholars to employ cash Waqf in such a way that can serve society's needs by highlighting the significance of cash Waqf as a fundraising scheme. Moreover, shed some light on the modus Operandi of investment for cash Waqf while guaranteeing its perpetuity.

Since management systems are facing number of challenges to make it productive, transparent, dynamic and innovative in the utilization of the Waqf properties recommended solution for these problems are good governance, creating secondary projects to generate a regular flow of incomes for insufficient project (Mokhtar et al., 2015). To be said, accounting and reporting practices seem to exist in the Awqaf entity, notable changes remain essential to guarantee accountability that could be continuously enhanced and uphold. Sharing the reports with the contributors, this might prompt them to increase their contribution. Furthermore, they will be an indispensable part of the advertisement campaign when Mutawallis address the purpose of Waqf properly (Shukor et al., 2015).

Aside from perceived behavioral control and religiosity other factors should be addressed which for example cash Waqf awareness and cash Waqf (dakwa) "peer influence", "self-efficacy", impact, this will open new broaden insight how waqif performs. Moreover, factors that influence individuals to donate continually should be examined, because the information will enable the Nadzir (Waqf manger) to set future plans based on reliable forecast (taking into consideration Muslims occasions such as (Ramadan, Iduladha, Idulfitri, and Milad). Awareness and willingness towards technological Waqf in the 4.0 era, In addition to contemporary issues related to encrypted cash Waqf 
must be enhanced (Amin et al., 2014). Studies on transferring cash Waqf from country to another is highly encouraged, since Muslim and non-Muslim endowment for conflicted countries could be managed in sustainable way.

Since cash been started in those countries at present, countries that accept and practice cash Waqf are Pakistan, Iraq, Turkey, Iran, Syria, India, Egypt, and Burma (Rashid, 2003). However, we have found no previous study addressed the context of the above-mentioned countries. It is crucial to learn from their experience since the cash Waqf initiative has been highlighted in these counties. It has been discussed thoroughly that public literacy about cash Waqf is on its low level, which is vital to be enhanced since they are the main contributors. Convincing and enhancing public awareness is crucial to uplift cash Waqf potential to a higher level. Some potential factors such as Waqf awareness and cash Waqkf dakwa impact could provide new insights on how Waqif perform such divine giving in order to address the aforesaid limitation. Moreover, an intensive advertisement campaign is highly recommended and this could be started from Friday prayer Minbar (Pulpit).

\section{Conclusion and Recommendation}

\subsection{Conclusion}

This research presents the most current literature on the avenue addressed the cash Waqf for socio-economic advancement; This It is also could be considered as an eye-opener to encourage other researchers to work on cash Waqf broadly in a developing nation not only in Malaysia and Indonesia but extending it to rest of the world. Hence, exchanging its positive vibes. However, most of the studies addressed the Malaysian and Indonesian context, duplicate the previous research ideas with expanding the geographical limits of the previous research will be recommended, subsequently, attaining more reliable generalizable results.

Same with any study, our study has several limitations which is focusing on and addressing the literature related to cash Waqf, disregarding other Waqf practices such as Waqf Istibdal, Sukuk Waqf, and Waqf assets. In addition, reviewing only articles published 
in English. In adherence to our systematic review features, the in-hand research handles all related studies to cash Waqf irrespective of their type and status. To ensure the so-called "publication equality". All the unpublished attempts have been excluded from this study, as it is difficult to be accessed. This study accepted all the published articles irrespective to the location and landmass as long the article presented in English, and during the study period spanning 2002-2019. This study dose not only identify the gaps for the contemporary scholars but provide a venue to establish more comprehensive work based on the presented information.

\subsection{Recommendations}

Waqf activities should be given a wider attention. For instance, extending the proposed models to cover a wider range of SDGs. Waqf Manager should always stress on the transparency in all the transitions, hence, enhancing its credibility. An established/professional entity should be considered to supervise and manage the cash funds. Hence, avoiding any potentially fraudulent activity among the Mutawallis as well as to perform evaluations on the Nadzir's performance. Moreover, the availability of such an entity will ensure the proper allocation of cash Waqf returns.

For academia and theoretical, more proposed models addressing he sustainable development goal (SDGs) should be taken into consideration, since cash Waqf enjoy high flexibility and could be directed to the desired way. Waqf in Muslim minority countries, usually studies focus to measure the impact of religiosity and other factor but they do not consider how to increase and propose a new hybrid cash Waqf model to enhance the participation in such an activity. Moreover, proposed model or the ones will be proposed in the future should be validated through interviews and surveys to assess the stakeholders' intentions to apply such a model. Seeking for people's preferred types of Waqf is crucial; it will help to develop the proper cash Waqf model. 


\section{References}

Adeyemi, A. A., Ismail, N. A., \& Hassan, S. S. B. (2016). An empirical investigation of the determinants of cash waqf awareness in Malaysia, Intellectual Discourse, 24.

Affandi, A., \& Nufus, D. N. (2010). Analysis on cash waqf return fund allocation in Indonesia: A case study in Indonesian waqf deposit. Paper presented at the Seventh International Conference-The Tawhidi Epistemology: Zakat and Waqf Economy, 119-135.

Alam, M. M., Shahriar, S. M., Said, J., \& Monzur-E-Elahi, M. (2018). Waqf as a tool for rendering social welfare services in the social entrepreneurship context. Global Journal Al-Thaqafah, 87-98.

Aliyu, S.U. (2019). Reflections on the socioeconomic role of waqf in an Islamic economic system. International Journal of Umranic Studies. 4(1), 3143.

Al-Zuhaili, W. (2004). Al-waqf, Al-Fiqh al-Islami wa Adillatuh, 4th ed., Dar alFikr, Damascus, 130-153.

Amin, H., Abdul-Rahman, A. R., Ramayah, T., Supinah, R., \& Mohd-Aris, M. (2014). Determinants of online waqf acceptance: An empirical investigation. The Electronic Journal of Information Systems in Developing Countries, 60(1), 1-18.

Amuda, Y. J., \& Embi, N. A. C. (2013). Alleviation of poverty among OIC countries through sadaqat, cash waqf and public funding. International Journal of Trade, Economics and Finance, 4(6), 403-408.

Amuda, Y. J., Embi, A. C., \& Babatunde, O. H. (2014). An agricultural approach to the commercialization of cash waqf between Malaysia and Nigeria. Journal of Advanced Management Science, 2(4)1-14.

Aria, M., \& Cuccurullo. C. (2017). Bibliometrix: An R-tool for comprehensive science mapping analysis. Journal of informetrics, 11(4), 959-975.

Aziz, M. R. A., Johari, F., \& Yusof, M. A. (2013). Cash waqf models for financing in education. Paper presented at the 5th Islamic Economic System Conference (IECONS 2013), 835-842.

Chowdhury, M. S. R., Ghazali, M.F., \& Ibrahim, M. F. (2011). Economics of cash waqf management in Malaysia: a proposed cash waqf model for practitioners and future researchers. African Journal of Business Management, 5(30), 12155-12163.

Duasa, J., \& Thaker, M. A. M. T. (2015, December 14-15). Proposed integrated cash waqf investment model for micro enterprises in Malaysia: an empirical analysis. Paper presented at the International Conference on Islamic Economics, Governance and Social Enterprise (IConIGS), Melaka. 
Aldeen, Ratih \& Herianingrum | Contemporary Issues on Cash Waqf: A Review of the Literature

Duasa, J., \& Thaker, M. A. M. T. (2016). A cash waqf investment model: an alternative model for financing micro-enterprises in Malaysia. Journal of Islamic Monetary Economics and Finance, 1(2), 161-188.

Duasa, J., \& Thaker, M. A. M. T. (2017). Proposed integrated cash waqf investment model for micro enterprises in Malaysia: an empirical analysis. Journal of Islamic Philanthropy and Social Finance, 1(2), 26-41.

Duasa, J., Thaker, M. A. M. T., Mohamed, M.O., Afroz, R., \& Abidin, R.Z. (2014, August 20-21). Micro enterprises in Malaysia: an empirical assessment on financial obstacles. Paper Presented at the International Borneo Business Conference (IBBC), Kuching, Sarawak.

Hassan, C. S. N. A., \& Rahman, A. A. (2018). The potential of cash waqf in the socio-economic development of society in Kelantan: a stakeholder's perspective. New Developments in Islamic Economics, Emerald Publishing Limited, 67-82.

Haron, M., Kamarudin, M. K., Fauzi, N. A., Ariff, M. M., \& Zainuddin, M. Z. (2016). Cash waqf collection: Any potential factors to influence it. International Journal of Business, Economics and Law, 9(2), 27-33.

Hosseini, S. M. S., Salari, T. E., \& Abadi, S. M. N. Z. (2014). Study of cash waqf and its impact on poverty: case study of Iran. Atlantic Review of Economics, 5 (2), 1-19.

Ibn, Qudamah (1998), Al-Mughnī, D_ar al-Kit_ab al-'Arabī, Beirut.

Ibrahim, H., Amir, A., \& Masron, T. A. (2013). Cash wagf: An innovative instrument for economic development. International Review of Social Sciences and Humanities, 6(1), 1-7.

Johari, F., Alias, M. H., Aziz, A., Ridhwan, M., Kefeli, Z., Ahmad, N., \& Ibrahim, P. H. (2015). Identifying the potential of continuity in cash waqf contribution: a descriptive analysis. The Journal of Muamalat and Islamic Finance Research, 20(4), 1-14.

Kachkar, O.A. (2017). towards the establishment of cash waqf microfinance fund for refugees. ISRA International Journal of Islamic Finance, 9(1), 81-86.

Kahf, M. (1999). Financing the development of awqaf property. The American Journal of Islamic Social Sciences, 16 (4), 39-66.

Kahf, M. (2003, January 6-7). The role of waqf in improving the ummah's welfare. Paper presented at the International Seminar on Waqf as a Private Legal Body, Medan, Indonesia.

Karim, S A. (2007). Contemporary waqf administration and development in Singapore. Paper presented at the Singapore International Waqf Conference, Singapore, 2-10.

Khademolhoseini, M. (2008). Cash-waqf: a new financial instrument for financing issues: an analysis of structure and Islamic justification of its commercialization. Imam Sadiq University. 
Aldeen, Ratih \& Herianingrum | Contemporary Issues on Cash Waqf: A Review of the Literature

Lahsasna, A. (2010). The role of cash waqf in financing micro and medium sized enterprises (MMEs). Paper presented at the Seventh International Conference-The Tawhidi Epistemology: Zakat and Waqf Economy. 97-118.

Laldin, M .A. (2008). Fundamentals and practices in Islamic finance. Kuala Lumpur, Malaysia: International Shariah Research Academy for Islamic Finance (ISRA).

Mahamood, S. M. (2006). Waqf in Malaysia: legal and administrative perspective. Kuala Lumpur: Penerbit Universiti Malaya.

Masyita, D., Tasrif, M., \& Telaga, A. S. (2005, July 17-21). A dynamic model for cash waqf management as one of the alternative instruments for the poverty alleviation in Indonesia. Paper presented at the 23rd International Conference of the System Dynamics Society, Massachusetts Institute of Technology (MIT), Cambridge, MA.

Mauluddin, M. I., \& Rahman, A. A. (2018). Cash Wagf from the perspective of Majelis Ulama Indonesia (MUI) and the scholars of Aceh: an analysis. New Developments in Islamic Economics, Emerald Publishing Limited, 49-66.

Mohsin, M. I. A. (2013). Financing through cash-waqf: a revitalization to finance different needs. International Journal of Islamic and Middle Eastern Finance and Management, 6(4), 304-321.

Mohammad, M. T. S .H. (2011). Towards an Islamic social (waqf) bank. International Journal of Trade, Economics and Finance, 2(5), 381386.

Mohammad, M. T. S. H. (2009). Alternative development financing instruments for waqf properties. Malaysian Journal of Real Estate, 4(2), 45-59.

Mohsin M. I. A. (2008). Cash waqf a new financial product model aspects of shariah principles on its commercialization. Paper presented at Islamic Banking, Accounting and Finance (iBAF).

Mokhtar, F. M., Sidin, E. M., \& Abd Razak, D. (2015). Operation of cash waqf in Malaysia and its limitations. Journal of Islamic Economics, Banking and Finance, 1(13) 1-15.

Mubyarto (1988). Etika Keadilan Sosial Dalam Islam. In Mubyarto, et al. (Eds.). Islam dan Kemiskinan. Bandung, Indonesia: Pustaka.

Nadwi, M. A. (2015). A new framework of corporate governance for waqf: a preliminary proposal, Islam and Civilizational Renewal, 6 (3), 353-370.

Nadwi, M. A. \& Kroessin, M. (2013). Cash waqf: exploring concepts, jurisprudential boundaries and applicability to contemporary Islamic microfinance. Islamic Relief Worldwide Working Paper Series, no. 2013Ox, Birmingham.

Nadya, P. S., Alwyni, F. A., Hadiyati, P., \& Iqbal, M. (2019). Strategy of Optimization Cash Waqf In Indonesia. Jurnal Syarikah: Jurnal Ekonomi Islam, 4(2), 108-121. 
Aldeen, Ratih \& Herianingrum | Contemporary Issues on Cash Waqf: A Review of the Literature

Nahar, S. H., \& Yaacob, H. (2011). Accountability in the sacred context: the case of management, accounting and reporting of a Malaysian cash awqaf institution. Journal of Islamic Accounting and Business Research, 2(2), 87-113.

Nurrachmi, R. (2012), Implication of cash waqf in the society, Al-infaq, 3(2).

Osman, A. F., Htay, S. N. N., \& Muhammad, M. O. (2012, April 12). Determinants of cash waqf giving in Malaysia: survey of selected works. Paper Presented in Workshop Antarbangsa Pembangunan Berteraskan Islam V (WAPI-5), Medan, Indonesia, 186-243.

Osman, A. F., Mohammed, M. O., \& Amin, H. (2014). An analysis of cash waqf participation among young intellectuals. Paper presented at Istanbul $9^{\text {th }}$ International Academic Conference (IIES), Turkey.

Osman, A. F., Mohammed, M. O., \& Fadzil, A. (2016). Factor influencing cash waqf giving behavior: a revised theory of planned behavior. Journal of Global Business and Social Entrepreneurship, 1(2), 12-25.

Perlis, K. M., Isa, M. B. M., Palil, R., \& Dolah, N. H. (2014). Online waqf acceptance and determinant factors. International Journal of Business, Economics and Law, 5(2), 28-35.

Pitchay, A., Meera, A. K. M., \& Saleem, M. (2015). Factors influencing the behavioral intentions of Muslim employees to contribute to cash-waqf through salary deductions. Journal of King Abdulaziz University: Islamic Economics, 28(1) 25-45.

Puad, N. A. M., Rafdi, N. J., \& Shahar, W. S. S. (2014). Issues and challenges of waqf instrument: A case study in MAIS. In E-proceedings of The Conference on Management and Muamalah, 978-983.

Rashid, S.K. (2003). Current waqf experiences and the future of waqf institution. Awqaf, 5, 5-26.

Ratnasari, R. T., \& Arifin, M. H., (2017, November 15). Theory of planned behavior in intention to pay cash waqf. Paper presented at the $1^{\text {st }}$ International Conference on Islamic Economics, Business, and Philanthropy (ICIEBP) 2017.

Rizal, H., \& Amin, H. (2017). Perceived ihsan, Islamic egalitarianism and Islamic religiosity towards charitable giving of cash waqf. Journal of Islamic Marketing, 8(4), 669-685.

Rusydiana, A. S., \& Devi, A. (2018). Elaborating cash waqf development in Indonesia using analytic network. International Journal of Islamic Business and Economics (IJIBEC), 2(1), 1-13.

Saifuddin, F. B., Kadibi, S., Polat, R., Fidan, Y., \& Kayadibi, O. (2014). The role of cash waqf in poverty alleviation: case of Malaysia. International Journal of Business, Economics and Law, 4(1), 171-179.

Sanusi, S., \& Shafiai, M. H. M. (2015). The management of cash waqf: toward socio-economic development of Muslims in Malaysia. Jurnal Pengurusan, 43, 3-12. 
Aldeen, Ratih \& Herianingrum | Contemporary Issues on Cash Waqf: A Review of the Literature

Shukor, S. A., Anwar, I. F., \& Sabri, H. (2015, April). Muslims participation in cash waqf: the case of Malaysia. Paper presented at the International Conference of Management Sciences. Malaysia.

Shukor, S. A., Anwar, I. F., Aziz, S. A., \& Sabri, H. (2017a). Muslim attitude towards participation in cash waqf: antecedents and consequences. International Journal of Business and Society, 18(1), 193-204.

Shukor, S. A., Anwar, I. F., Sabri, H., Aziz, S. A., \& Ariffin, A. R. M. (2017b), Giving behaviour: who donates cash waqf Malaysian. Journal of Consumer and Family Economics, 5(2), 87-100.

Siswantoro, D., \& Dewi, M. K. (2007). The effectiveness of waqf fund raising through mutual fund in Indonesia. In M. Kahf, and S. M. Mohamood (Eds.), Singapore International Waqf Conference, p. 7

Siswantoro, D., Rosdiana, H., \& Fathurahman, H. (2018). Reconstructing accountability of the cash waqf (endowment) institution in Indonesia. Managerial Finance, 44(5), 624-644.

Shinkafi, A. A., \& Ali, N. A. (2017). Contemporary Islamic economic studies on Maqasid Shari'ah: a systematic literature review. Humanomics. 33(3), 315-334.

Suhaimi, F. M., Ab Rahman, A., \& Marican, S. (2014). The role of share waqf in the socio-economic development of the Muslim community: The Malaysian experience. Humanomics, 30(3), 227-254.

Sulaiman, S., Hasan, A., Noor, A. M., Ismail, M. I., \& Noordin, N. H. (2019). Proposed models for unit trust waqf and the parameters for their application. ISRA International Journal of Islamic Finance, 11(1), 62-81.

Thaker, M. A. M. T. (2018). A qualitative inquiry into cash waqf model as a source of financing for micro enterprises, ISRA International Journal of Islamic Finance. 10 (1), 19-35

Thaker, M.A.M.T., Mohammed, M.O., Duasa, J., \& Abdullah, M.A. (2016). The behavioral intention of micro enterprises to use the integrated cash waqf micro enterprise investment (ICWME-I) model as a source of financing. Gadjah Mada International Journal of Business, 18(2), 111.

Thaker, M. A. M. T., Mohammed, M. O., Duasa, J., \& Abdullah, M. A. (2016). Developing cash waqf model as an alternative source of financing for micro enterprises in Malaysia, Journal of Islamic Accounting and Business Research, 7(4), 254-267.

Toraman, C., Tunçsiper, B., \& Yilmaz, S. (2007, August 9-11). Cash Awqaf in the Ottomans as philanthropic foundations and their accounting practices. Paper presented at the 5th Accounting History International Conference, Banff, Canada.

Victoria, O. A., \& Ong, R. (2019). Law Development of Wagf Al-Nuqud (Cash Waqf) Towards Electronic Waqf (E-Waqf) Based on Public Welfare. Law Development Journal, 1(1), 13-17. 
Aldeen, Ratih \& Herianingrum | Contemporary Issues on Cash Waqf: A Review of the Literature

Wafa, S. M. G. W. S. A., (2010, January 6-7). Development of waqfs for education in Malaysia. In A.G. Ismail, M.E.M. Hassan, N. Ismail, \& S. Shahimi (Eds.), Proceedings of the $7^{\text {th }}$ International Conference on The Tawhidi epistemology: Zakat and waqf economy, 137-153.

Witjaksono, B. (2018). Factors which influence the intention of community in cash waqaf in sharia banking with theory planned behaviour (TPB) modification approach. Jurnal Ekonomi. 9 (2).

Yaacob, H. (2013). Waqf history and legislation in Malaysia: A contemporary perspective. Journal of Islamic and Human Advanced Research, 3(6), 387-402.

Yusof, M. F. M., Hasarudin, M.H., \& Romlin, N. (2014). Cash waqf and infaq: a proposed e-philanthropy in Malaysia. Jurnal Kemanusiaan, 22(1), pp. 110.

Zabri, M. Z. M., \& Mohammed, M. O. (2018). Examining the behavioral intention to participate in a cash waqf-financial cooperativemusharakah mutanaqisah home financing model. Managerial Finance, 44(6), 809-829.

Zarka, M. A. (2007, April 14). Leveraging philanthropy: monetary waqf for micro finance. Paper presented at the symposium towards an Islamic micro-finance, Harvard Law School, Massachusetts. 